\title{
The Impact of the Agriculture in Decreasing the Unemployment Rate
}

\author{
Ardi PARDUZI ${ }^{\star}$, Myrvete BADIVUKU-PANTINA ${ }^{\star \star}$
}

\begin{tabular}{l}
\hline \multicolumn{1}{c}{ A R T I C L E I N F O } \\
\hline Article history: \\
Accepted June 2020 \\
Available online August 2020 \\
\hline JELClassification \\
O13, 015 \\
Keywords: \\
Agriculture, Unemployment rate, \\
OLS models, Kosovo
\end{tabular}

OLS models, Kosovo

\begin{abstract}
A B S T R A C T
A country's overall economic health is measured by looking at economic growth, economic development, and unemployment rate. Countries with lack of capital, infrastructure and isolation with other countries, factors that would affect a sustainable economic stability and maintaining low unemployment rate should focus on agricultural development. The purpose of this paper is to analyze the factors that will affect the development of agriculture which would then directly affect an economic stability and reduce unemployment rate. Factors we have considered are: the number of employees in the agricultural sector, the area of arable land, the export of agricultural products, GDP growth, unemployment rate, the development of the industrial sector and the development of the services sector, all of these as independent variables which we compared with development of the agricultural sector as dependent variable.
\end{abstract}

(C) 2020 EAI. All rights reserved.

\section{Introduction}

In the developing countries that entered lately in the EU, in our case the five Balkan countries are now among the developed countries and the objective of each of these countries is to develop the sector of agro-industry. To move to this sector, the agricultural sector must be well developed, knowing that agriculture for many countries is the main source of employment but varies from country to country but it ranges from $50 \%$ to $90 \%$ (Focus on the Global South, 2013) of all employment rate.

The change in productivity in agriculture is the result of innovation and technological changes in many cases the inability to adapt to those changes has led countries to stagnate their development, for this reason we have taken the technology factor for analysis not only to see how much the country is dedicated to the development of technology as a global trend but also its adaptation into the agriculture sector.

This research will also serve as an argument for countries that have agriculture as a primary sector in GDP growth as well as for west Balkan countries whose goals are to become part of the EU.

Factors that are influencing countries to have a greater growing focus on agriculture trade are: population growth, high unemployment rate, expanding biofuel production, food insecurity, land grabbing and climate change. These factors as well as the food price crisis in 2007 have revived an interest in agriculture as an important sector of activity in the world economy (Bacchetta M, 2009).

The effect of unilateral agricultural liberalization on general employment rate may be the opposite effect on agricultural employment. Unilateral liberalization in agriculture may reduce employment in that sector, but increases employment in industrial sectors (Jansen $M, 2010$ ).

For example, liberalizing imports of meat, milk, cereals, vegetables, and wine imports to Bosnia and Herzegovina as part of WTO membership would shift production and workers to these agricultural subsectors.

Agricultural modernization is an ongoing process and is the essence of progress in agriculture and rural areas. The modernization of the production methodology in agriculture sector through the implementation of new technological implementations comes from the presence of the so-called "technology routine". This results in a constant need with technological progress, or even the need to lead this race between farmers. Low food demand flexibility and higher supply flexibility often lead to decrease prices (KusZ $D, 2014)$. 


\section{Problem statement, objective and hypotheses}

The agricultural sector has made a significant contribution to the economic prosperity of developed countries and the role of economic development and decreases of unemployment rate for all developing and less developed countries are vital importance (Deepa P, 2012).

So, the development of agriculture has an important role not only in increasing the GDP but also in economic development. The increase in employment in the agricultural sector affects the decreasing of unemployment rate, especially for countries with no qualified population.

In most of poor countries, the majority of the population lives in rural areas and earns mainly from agriculture. Agriculture has a significant impact of economic activity in developing countries, with about $25 \%$ of GDP in poor countries coming from this sector.

Agricultural sector participation means that changes of agriculture have major impact on macroeconomic variables, including economic growth and increasing the employment rate. Agriculture sector does not necessarily mean that it should be a major sector for economic growth and decreasing the unemployment rate, because in most of developing countries agriculture sector has very low productivity compared to developed countries.

For countries with large populations and limited access to international markets, agricultural development is essential for economic growth and decreases of unemplyment rate. Given all this, Kosovo is a potential country to explore the relationship between agriculture and employment rate.

In developing countries about 50 percent of workers are employed in the agricultural sector, while in developed countries agriculture employs just over 4 percent of workers.

Agriculture is a key sector in Kosovo's economy, but after the last war the decline in agricultural production and the trade deficit of agribusiness has deepened, however through local subsidies and international donations, Kosovo claims that agriculture becomes an important sector of economic growth and decreasing of unemployment rate.

Data from the experiences of other countries suggest that agriculture has often played an important role in the country's development, especially the Green Revolution in Asia. On the other hand, the experiences of successful countries in Asia and Latin America suggest that the contribution of the agricultural sector ensures an internal economic stability (Diao X, 2010).

This study will have scientific and practical importance, for designing policies for agricultural development, as an important sector for decreasing unemployment rate in Kosovo.

First, the study will provide an analysis of agricultural development, how much it affects economic growth and decreasing of unemployment rate by comparing Kosovo's data with those of Slovenia.

Second, this research will provide evidence for decision-makers to increase investments in agriculture or if results of agricultural development do not have much effect on decreasing unemployment rate then the investment approach shifts into industry, technology, services, etc (Agriculture Goods, 2020).

Increasing the number of employees in the agricultural sector, encourages productivity increasing, income increasing which is manifested by increasing GDP through increased investment and consumption.

\section{H1: Agricultural development has impact on unemployment rate} H0: Agricultural development does not have impact on unemployment rate.

\section{Problems and methods}

We have used the specification of the econometric model of theory, to understand the relationship between dependent and independent variables. To select the specified model we have taken as a basis $\mathrm{R}^{2}$. squared which measures the percentage of variation in the dependent variable that is explained by the change in the explanatory variables and the Radj- squared coefficient of determination.

The purpose of this empirical study is to analyze the factors that would affect changes in agricultural development during the period 2008-2017.

In this empirical study the data are presented in panel form. The number of observations is 20, more specifically there are 2 countries for 10 years, Kosovo and Slovenia; explaining the impact of agricultural development on the unemployment rate for the period (2008-2017)

There are a total of 8 variables in this model: Agricultural Development as a dependent variable (Y) while as independent variables are: Employment in the agricultural sector, arable land, export of agricultural products, domestic GDP, unemployment rate, the sector of industry and services sector.

Table 1. Statistical data analysis

\begin{tabular}{|c|c|c|c|c|c|c|c|c|c|}
\hline Country & Year & $\begin{array}{l}\text { Agriculture } \\
\text { (Y) }\end{array}$ & $\begin{array}{c}\text { Employment } \\
\text { in } \\
\text { agriculture }\end{array}$ & $\begin{array}{l}\text { Arable } \\
\text { land }\end{array}$ & $\begin{array}{c}\text { Export- } \\
\text { agricultural } \\
\text { products }\end{array}$ & $\begin{array}{c}\text { GDP } \\
\text { (Annual } \\
\text { growth) }\end{array}$ & $\begin{array}{l}\text { Unemployment } \\
\text { rate }\end{array}$ & $\begin{array}{l}\text { Industry } \\
\text { (annual } \\
\text { growth) }\end{array}$ & $\begin{array}{l}\text { Services } \\
\text { (annual } \\
\text { growth) }\end{array}$ \\
\hline Kosovo & 2008 & $14.79 \%$ & $3.13 \%$ & $27.11 \%$ & $10.46 \%$ & $2.64 \%$ & $47.50 \%$ & $23.09 \%$ & $3.60 \%$ \\
\hline Kosovo & 2009 & $14.13 \%$ & $3.17 \%$ & $27.80 \%$ & $12.09 \%$ & $3.34 \%$ & $45.40 \%$ & $12.03 \%$ & $3.79 \%$ \\
\hline Kosovo & 2010 & $13.60 \%$ & $3.07 \%$ & $28.32 \%$ & $8.36 \%$ & $3.31 \%$ & $40.90 \%$ & $4.35 \%$ & $4.53 \%$ \\
\hline
\end{tabular}




\begin{tabular}{|c|c|c|c|c|c|c|c|c|c|}
\hline Country & Year & $\begin{array}{c}\text { Agriculture } \\
\text { (Y) }\end{array}$ & $\begin{array}{c}\text { Employment } \\
\text { in } \\
\text { agriculture }\end{array}$ & $\begin{array}{l}\text { Arable } \\
\text { land }\end{array}$ & $\begin{array}{c}\text { Export- } \\
\text { agricultural } \\
\text { products }\end{array}$ & $\begin{array}{c}\text { GDP } \\
\text { (Annual } \\
\text { growth) }\end{array}$ & $\begin{array}{l}\text { Unemployment } \\
\text { rate }\end{array}$ & $\begin{array}{r}\text { Industry } \\
\text { (annual } \\
\text { growth) }\end{array}$ & $\begin{array}{r}\text { Services } \\
\text { (annual } \\
\text { growth) }\end{array}$ \\
\hline Kosovo & 2011 & $12.76 \%$ & $3.00 \%$ & $29.53 \%$ & $8.20 \%$ & $4.81 \%$ & $37.23 \%$ & $3.92 \%$ & $5.97 \%$ \\
\hline Kosovo & 2012 & $12.20 \%$ & $3.01 \%$ & $30.55 \%$ & $11.53 \%$ & $2.89 \%$ & $30.90 \%$ & $8.29 \%$ & $5.03 \%$ \\
\hline Kosovo & 2013 & $11.99 \%$ & $3.09 \%$ & $33.40 \%$ & $11.89 \%$ & $3.43 \%$ & $30.00 \%$ & $8.45 \%$ & $4.41 \%$ \\
\hline Kosovo & 2014 & $11.88 \%$ & $3.52 \%$ & $35.20 \%$ & $12.13 \%$ & $1.19 \%$ & $35.30 \%$ & $-0.74 \%$ & $5.34 \%$ \\
\hline Kosovo & 2015 & $10.32 \%$ & $3.83 \%$ & $34.13 \%$ & $12.80 \%$ & $4.09 \%$ & $32.90 \%$ & $6.93 \%$ & $2.49 \%$ \\
\hline Kosovo & 2016 & $10.46 \%$ & $4.31 \%$ & $34.71 \%$ & $14.61 \%$ & $4.05 \%$ & $27.50 \%$ & $1.64 \%$ & $2.59 \%$ \\
\hline Kosovo & 2017 & $9.13 \%$ & $4.51 \%$ & $35.13 \%$ & $15.01 \%$ & $4.22 \%$ & $30.50 \%$ & $4.23 \%$ & $5.41 \%$ \\
\hline Slovenia & 2008 & $1.65 \%$ & $8.59 \%$ & $9.10 \%$ & $2.76 \%$ & $3.30 \%$ & $4.37 \%$ & $1.93 \%$ & $3.51 \%$ \\
\hline Slovenia & 2009 & $1.65 \%$ & $9.12 \%$ & $9.14 \%$ & $3.45 \%$ & $-7.79 \%$ & $5.85 \%$ & $-14.08 \%$ & $-3.80 \%$ \\
\hline Slovenia & 2010 & $1.72 \%$ & $8.81 \%$ & $9.16 \%$ & $3.46 \%$ & $1.23 \%$ & $7.23 \%$ & $0.18 \%$ & $1.83 \%$ \\
\hline Slovenia & 2011 & $1.98 \%$ & $8.59 \%$ & $9.15 \%$ & $3.51 \%$ & $0.64 \%$ & $8.16 \%$ & $-0.21 \%$ & $0.39 \%$ \\
\hline Slovenia & 2012 & $1.79 \%$ & $8.39 \%$ & $9.11 \%$ & $4.20 \%$ & $-2.67 \%$ & $8.84 \%$ & $-3.46 \%$ & $-1.62 \%$ \\
\hline Slovenia & 2013 & $1.79 \%$ & $8.50 \%$ & $9.18 \%$ & $3.60 \%$ & $-1.13 \%$ & $10.10 \%$ & $-1.75 \%$ & $-0.39 \%$ \\
\hline Slovenia & 2014 & $2.01 \%$ & $9.62 \%$ & $9.13 \%$ & $3.46 \%$ & $2.97 \%$ & $9.66 \%$ & $5.56 \%$ & $2.51 \%$ \\
\hline Slovenia & 2015 & $2.02 \%$ & $7.07 \%$ & $9.13 \%$ & $3.71 \%$ & $2.25 \%$ & $8.96 \%$ & $0.88 \%$ & $2.72 \%$ \\
\hline Slovenia & 2016 & $1.88 \%$ & $5.02 \%$ & $9.12 \%$ & $4.00 \%$ & $3.14 \%$ & $8.00 \%$ & $2.90 \%$ & $3.47 \%$ \\
\hline Slovenia & 2017 & $1.82 \%$ & $4.93 \%$ & $9.12 \%$ & $3.20 \%$ & $5.00 \%$ & $6.56 \%$ & $8.41 \%$ & $4.45 \%$ \\
\hline
\end{tabular}

Source: World Bank (2019), KSA (2019), Green Report (2018), IMF (2018), Eurostat (2019).

\section{Agro gro $=\beta 0+\beta_{1}$ (agro emply. $)+\beta_{2}$ (arable land $)+\beta_{3}$ (agro exp. $)+\beta_{4}($ gdp $)+\beta_{5}($ unemploy $)+\beta_{6}$ (industry) $+\beta_{7}$ (services) $+u_{1}$}

The database is obtained from World Bank, Eurostat, International Monetary Fund, KSA, Green Report, etc.

Econometric treatment for quantitative results is based on variance analysis and regression analysis, OLS, F-test and cross-database for testing these variables and then extends to panel data analysis

So the research will take place in three phases:

\section{$1 \quad$ Preparatory phase}

$2 \quad$ Statistical data research phase

3 Outcome processing phase

The preparatory phase - will begin with the collection and review of information through scientific literature, journals, publications which will be used in this research.

Statistical data research phase - will be based on the collected data, their analysis and description of variables interpreted.

Outcome processing phase - is the final stage where the research results will be processed and

\section{Results and discussions}

From the data presented in Table 1 we have interpreted the results from the analysis of correlation, regression, we have interpreted the best positive and negative result from the regression analysis also the hypotheses.

\section{Correlation Analysis.}

\section{Table 2. Correlation of variables}

- cor bujqesiay punesiminebujqesi tokaepunueshme exportproduktebujqesore gdprritjavjetore papunesia industriarritjavjetore sherbimet $>$ rritjavjetore

(obs=20)

\begin{tabular}{|c|c|c|c|c|c|c|c|c|}
\hline bujqesiay & 1.0000 & & & & & & & \\
\hline punesimine i & -0.8806 & 1.0000 & & & & & & \\
\hline tokaepunue e & 0.9074 & -0.8278 & 1.0000 & & & & & \\
\hline exportprod e & 0.8200 & -0.7635 & 0.9606 & 1.0000 & & & & \\
\hline gdprritjav e & 0.4244 & -0.5508 & 0.4472 & 0.4181 & 1.0000 & & & \\
\hline papunesia & 0.9834 & -0.8518 & 0.8825 & 0.8123 & 0.4220 & 1.0000 & & \\
\hline industriar e & 0.5806 & -0.5923 & 0.4135 & 0.4118 & 0.7139 & 0.6178 & 1.0000 & \\
\hline sherbimetr e & 0.6106 & -0.6622 & 0.5783 & 0.4882 & 0.8705 & 0.5811 & 0.6415 & 1.0000 \\
\hline
\end{tabular}

Source (from table 1)- Stata processing

To analyze the variables we have presented the correlation matrix, the ratio between employment in agriculture and agricultural development has an average negative relationship (-0.8) and is the only ratio in the analysis with negative relationship. The correlation with a positive average of 0.98 which means that the variable of unemployment has the most impact in agricultural development. Arable land in relation to 
agricultural development has a positive average correlation of 0.9. Export of agricultural products in relation to agricultural development have a positive correlation of 0.82 which is followed by the ratio of the service sector to agricultural development which have a positive correlation with a value of 0.61 . Industry and agricultural development have a positive average relationship with a correlation value of 0.58 . The ratio of GDP to agricultural development, have the lowest positive correction in value of 0.42 .

\section{Specification of the econometric model of theory}

In this part of the research we will first select the most specific model, then commenting the relevant values of the model. To select the specified model we have taken as guide the statistical values of R2 and R2adj where we tested the independent variables.

Table 3. Regression of variables

\begin{tabular}{|l|l|l|l|}
\hline Tabel & Model & $\mathbf{R}^{2}$-squared & Adj R-squared \\
\hline 1 & Agrogro, agroemploy & $\mathbf{0 . 8 3}$ & $\mathbf{0 . 8 2}$ \\
\hline 2 & Agrogro, agroemploy, arableland & $\mathbf{0 . 8 7}$ & $\mathbf{0 . 8 6}$ \\
\hline 3 & Agrogro, egroemploy, arableland, agroexp. & $\mathbf{0 . 8 9}$ & $\mathbf{0 . 8 7}$ \\
\hline 4 & $\begin{array}{l}\text { Agrogro, agroemploy, arableland, agroexp, } \\
\text { gdp. }\end{array}$ & $\mathbf{0 . 9 0}$ & $\mathbf{0 . 8 7}$ \\
\hline 5 & $\begin{array}{l}\text { Agrogro, agroemploy, arableland, agroexp, } \\
\text { gdp, unemploy. }\end{array}$ & $\mathbf{0 . 9 8}$ & $\mathbf{0 . 9 7}$ \\
\hline 6 & $\begin{array}{l}\text { Agrogro, agroemploy, arableland, agroexp, } \\
\text { gdp, unemploy, Industry. }\end{array}$ & $\mathbf{0 . 9 8}$ & $\mathbf{0 . 9 7}$ \\
\hline $\mathbf{7}$ & $\begin{array}{l}\text { Agrogro, agroemploy, arableland, agroexp, } \\
\text { gdp, unemploy, Industry, service. }\end{array}$ & $\mathbf{0 . 9 8}$ & $\mathbf{0 . 9 8}$ \\
\hline
\end{tabular}

Based on the comparative analysis in this study we conclude that the most powerful model is the 7 th model which includes variables as: agrogro, agroemply, arableland, agroexp, gdp, pregnanty, industry, service where $\mathrm{R}^{2}$-square and Radj-squared have the largest values, $\mathrm{R}^{2}$-squared is 0.9874 and Radj-squared 0.9801 . This means that the variables X explain $98.74 \%$ of the variation in Y. The remaining $1.26 \%$ of the variation is explained by other factors of $X$ that affect the $Y$ and are summarized in the error term.

Table 4. FE-test

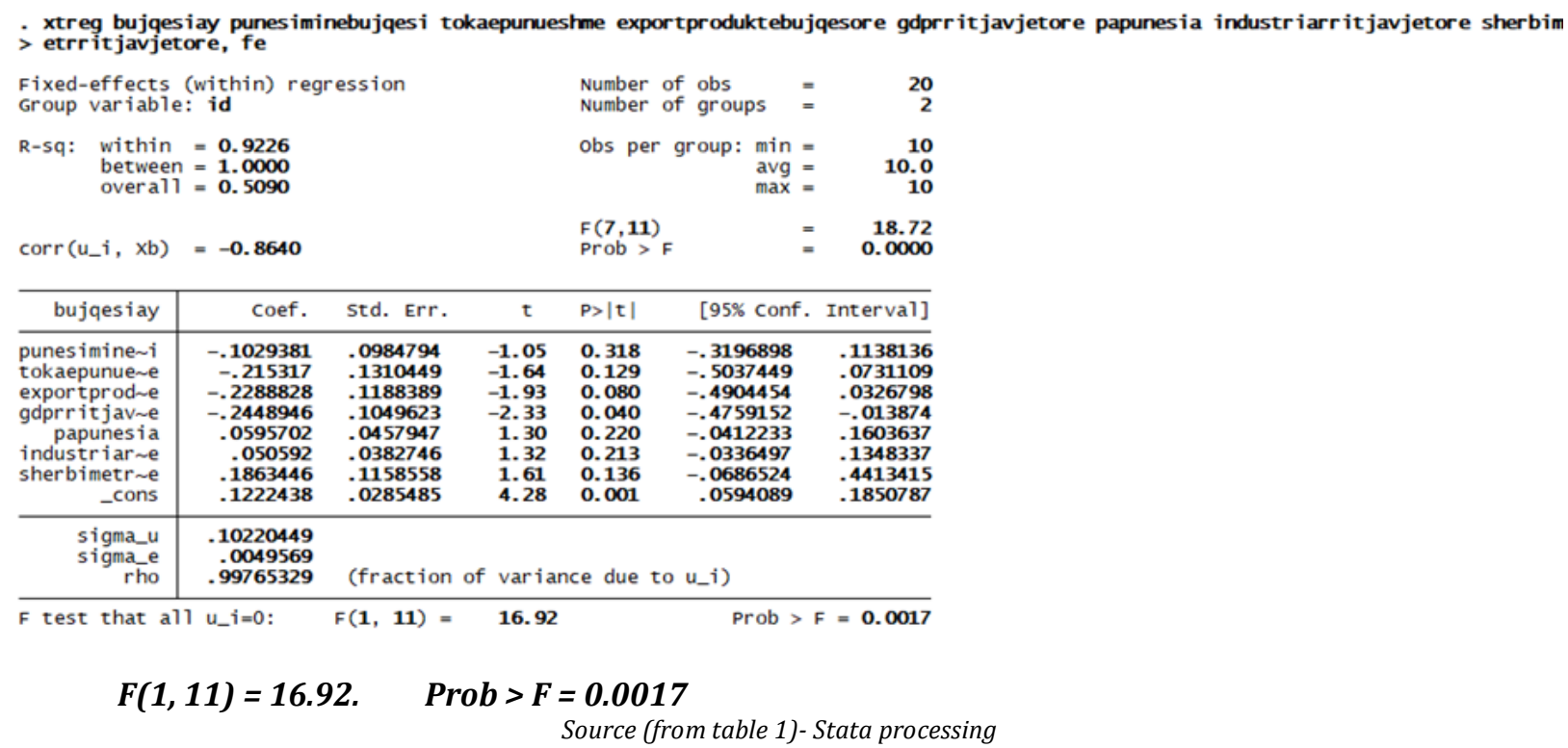

In our case, the probability of making the error of type 1 , in the $\mathrm{F}$ test of the fixed effect results is equal to 0.0017 , gives us to understand that $0.17 \%$ are likely to become error of type 1 if we reject the hypothesis 0 , i.e. we do not reject the hypothesis 0 , which means that the fixed effects are equal to 0 , we accept the hypothesis 0, which means that the fixed effects are insignificant. We could say that the fixed effects are not statistically significant, so in our model the OLS estimator is preferred more than the evaluator of fixed effects FE. 
make significant contributions against poverty, employment in agriculture sector could play a crucial role in achieving this.

For countries with large populations and limited access to international markets like Kosovo, agricultural development is essential for economic growth. For other countries, the importance of agricultural growth will depend on relative applicability and the cost of food imports.

Specifically, the main determinants of the agricultural sector were arable land, agricultural exports, GDP, unemployment, the industrial sector and the services sector, which have a positive impact on the development of the agricultural sector, while only variable the employment in agricultural sector has a negative and is inexplicable in economic theory, because an employment in the agricultural sector should have a positive impact on this sector but according to the results of regression it turns out to be negative.

Over 60 percent of the global agricultural workforce is estimated to be informally employed. The World Bank estimates that three out of every four poor people live in rural areas in developing countries, and their livelihoods depends on agriculture. Policy changes in the agricultural sector are likely to have a significant impact on poverty (Bacchetta M, 2009).

\section{References}

1. World Bank- https://data.worldbank.org/

2. International Monetary Fund - https://www.imf.org/en/Countries/UVK

3. KSA-Kosovo Agency of Statistics - https://ask.rks-gov.net/sq/agjencia-e-statistikave-te-kosoves/bujqesi/regjistrimi-i-bujqesise

4. Eurostat-https://ec.europa.eu/eurostat/data/database

5. Green Report-https://www.mbpzhr-ks.net/repository/docs/Raporti_i_Gjelber_2017_Alb_Final.pdf

6. Report of Focus on the Global South (March 2013)- "21 ${ }^{\text {st }}$ Century trade wars: Big economies and their aggressive push for new generation free trade agreements"

7. Marc Bacchetta (2009)- "Globalization and informal jobs in developing countries"

8. Marion Jansen (2010). "Developing countries, standards and the WTO", in The Journal of International Trade \& Economic Development, Vol. 19, page163-85.

9. Dariusz Kusz "Modernization of agriculture vs sustainable agriculture” page 171-177

10. Pragyan Deepa. "Role of agriculture in the economic development of a country"

11. Xinshen Diao. (November 2010)- "The economic importance of agriculture for sustainable development and poverty reduction"

12. Article of $A G$." The importance of Agriculture"

13. Marc Bacchetta (2009)- "Globalization and informal jobs in developing countries" - page 27. 